\title{
Government Policies on Agro-Tourism in Indonesia
}

\author{
ROSLINA \\ Department of Management, Faculty of Economics and Business \\ Universitas Lampung \\ J1. Soemantri Brojonegoro 1, Bandar Lampung, Lampung, 35141 \\ INDONESIA \\ RITA NURMALINA \\ Department of Agribusiness, Faculty of Economics and Management \\ Institut Pertanian Bogor \\ Jl. Kamper, Wing 4 Level 5, IPB Darmaga Campus, Bogor, 16680 \\ INDONESIA \\ MUKHAMAD NAJIB \\ Department of Management, Faculty of Economics and Management \\ Institut Pertanian Bogor \\ Jl. Agatis IPB Darmaga Campus, Bogor, 16680 \\ INDONESIA \\ YUDHA HERYAWAN ASNAWI \\ School of Business \\ Institut Pertanian Bogor \\ Jl. Raya Pajajaran, Bogor, 16151 \\ INDONESIA
}

\begin{abstract}
In developing countries, tourism positions the government not just as a policymaker, but also as a party that assists in the implementation of policies. Government initiatives towards the promotion of agrotourism, for example, are implemented by agro-tourism-related legislation and policies. However, agro-tourism development has not been optimal due to a lack of communication and coordination between parties, as well as inadequate execution of legislation or regulations controlling agro-tourism. The purpose of this study was to assess and examine government agro-tourism legislation and policies in Indonesia. The study is qualitative in nature, evaluating and analysing ten government's agro-tourism legislation and policies, with data collected through document analysis and in-depth interviews and analysed descriptively. The findings demonstrate that the government's agro-tourism regulations include controlling cross-sectoral collaboration in agro-tourism development, certification for agro-tourism guides, the establishment of agro-tourism commissions, and agrohorticulture business arrangements, among other things. Regulations and policies are ineffectual because there is a lack of engagement, coordination, and synergy among the parties involved in agro-tourism. Collaboration is required not just in terms of bureaucracy, but also in terms of resources in order to establish, promote, and maintain agro-tourism sustainability. The suggestions and limitations of the current study are also discussed.
\end{abstract}

Key-Words: - agro-tourism, governance policy, regulation, tourism development, environmental concern

Received: May 21, 2021. Revised: December 6, 2021. Accepted: January 8, 2022. Published: January 10, 2022.

\section{Introduction}

It is widely accepted that tourism is intertwined with political, economic, and social factors that affect a variety of stakeholders. The government's role in tourism is expanding, not just in terms of economics, but also in terms of sociocultural, political, and environmental awareness [1]. With tourism-related institutions, the government plays an important role in tourism development [2] and has the capacity and power to support and coordinate various stakeholders [3].

Tourism is extremely susceptible to distortions and failures, emphasizing the critical role of 
government [4]. Government engagement in tourism is evident in activities such as providing infrastructure and amenities, defining policies, planning, funding, promotion, and regulation, developing tourist destinations, identifying tourist sites, and establishing human resource requirements for tourism [3]-[5].

However, government involvement in tourism frequently encounters difficulties due to the implementation of established policies, a lack of coordination, weak governance, and top-down planning [1], [5]. Establishing laws that favor a particular set of individuals or that result in an excessively complex bureaucracy can result in the tourism sector's failure [5]. The government's failure has a detrimental effect on the tourism sector in the same way that natural and environmental disasters, terrorism, contagious diseases, and conflict have a detrimental effect on the tourism industry [6].

Tourism in Indonesia is classified under three product lines: nature tourism, cultural tourism, and man-made tourism, as well as 23 more tourism activities, including agro-tourism [7]. Agro-tourism is a term used to describe a variety of activities produced on farms to attract visitors and engage them in the agricultural process for recreational or leisure purposes [8], [9]. Agro-tourism is gaining popularity and recognition as a method for agricultural development and rural development [10], [11]. Since 1989, Indonesia has been developing agro-tourism through collaboration between the Ministry of Agriculture and the Ministry of Tourism, Post, and Telecommunications. In Indonesia, agro-tourism is regulated by a number of government agencies, including the Ministry of Agriculture, the Ministry of Tourism and Creative Economy, and the Ministry of Public Works and Public Housing.

In Indonesia, marketing agro-tourism is inextricably linked to the government's support through various government policies and initiatives in collaboration with tourism business operators. However, tourism businesses in a number of Indonesian tourist sites have been deemed to be underdeveloped due to a lack of tourists using tourism businesses' facilities and services [7]. Government policies promoting agro-tourism are represented in agro-tourism-related rules and policies. [12] stated that policy is determined by the government's willingness or inability to act. Governments decide policies in developing nations, and their effectiveness is defined by the extent of stakeholder participation and collaboration, as well as the evaluation and effective execution of decisions [13]. Thus, the government can be defined as the party that not only formulates policies but also assists in its implementation [14]. There is still a dearth of study on agro-tourism policies (see, for example, [15], [16]), owing to the fact that the majority of policy research is conducted on tourism for recreation and village tourism [4], [17]-[21]. Therefore, the purpose of this study was to assess and examine the execution of government agrotourism legislation and policies in Indonesia.

\section{Tourism Policy}

Government policy is a strategy of action that serves as a guide for selecting from numerous available possibilities [14] or a practice of translating official assertions into quantifiable and actionable indicators [22]. The participation and collaboration of stakeholders in the implementation of policies determines success, however in developing countries, policies are generally established by the government [13].

[23] stated tourism policy is defined as a set of rules, norms, directions, objectives, and development or promotion tactics that serve as a framework for collective and individual actions that affect long-term tourism development. It serves as a road map for the tourism industry in terms of government, development, and promotion [13]. Tourism policy will determine the actions of a country, province, district, or destination in developing and promoting tourism [14]. Tourism policy will define the roles of tourism operators, create activities and standards of behaviour for the benefit of tourists, and provide broad direction and guidance to all stakeholders [24]. The goal of tourism policy is to ensure that visitors receive the best possible service and have an unforgettable experience [23].

\section{The Role of Government}

Tourism's implementation requires the cooperation of both the public and private sectors. The growth of tourism has expanded the government's role beyond economics to include sociocultural responsibilities, political accountability, and environmental concern [1]. The government has a tourist agency that is responsible for tourism development and plays a critical role in its growth [2]. The government's role in tourism development is critical, particularly in terms of legislation, financing, planning, and tourism industry policies [14]. However, there are various inadequacies in this respect, including the government's top-down 
decision-making, ineffective planned implementation, a lack of coordination, and inadequate governance, which are frequently expressed to the government [5].

Previous research on the government's role in tourism has been conducted. For example, the Korean government seeks to bridge the divide between cities and villages by promoting urbanrural exchange programmes, tourism, or leisure activities such as green businesses and farm tourism, in rural, mountainous, and coastal areas [25]. [4] examined the Honduran government's role in agro-tourism development through a top-down strategy (central and local government) and bottom-up initiatives for agro-tourism development. In this situation, the bottom-up method incorporates the private sector, specifically farmers and tourism operators, such as hotel and restaurant managers and travel agencies. The research utilised stakeholder interviews to ascertain the government's role in tourism growth. The results of the interviews were utilised to create a semi-structured questionnaire to help better understand the government's role. The findings indicate that the government is involved in policy formulation (registration and licencing, taxes, and bureaucratic procedures), marketing and advertising, financial opportunities, information access (education and training, statistical data gathering), and infrastructure development.

[26] examines institutional collaboration in Ghana's tourist sector in terms of stakeholders' visions for tourism development, collaboration and coordination within the public sector and between the public and private sectors, as well as the barriers to and facilitators of collaboration and coordination. According to the findings of extensive interviews with key stakeholders and an examination of policy papers, there is a low level of collaboration across tourism institutions in Ghana, both in the public and commercial sectors. [27] looks into the impact of government policies on the competitiveness of destinations in Central America's emerging countries, including Belize, Costa Rica, El Salvador, Guatemala, Honduras, Nicaragua, and Panama. These countries are attempting to restructure their economies and shift away from agriculture and toward service-based businesses. The findings of the study show that government policies influence destination competitiveness in a variety of ways, with some policies having a greater impact than others, for example, increasing transparency about the level of corruption has a positive impact on destination competitiveness, whereas lowering taxes does not.
Policies that are either overly restrictive or too liberal can hasten or slow the development of a destination, lowering its competitiveness. Tourism has emerged as a major driver of economic growth and job creation, demonstrating the importance of being competitive in the marketplace. In order to succeed, tourism destinations must learn to think more like businesses and innovate in order to develop new products, markets, and customers. Governments also play important roles in tourism development, with involvement ranging from a low to a high level depending on the country [28].

\section{Methodology}

The study is qualitative in nature, consisting of an examination of ten agro-tourism legislation and policies. Through the document analysis, data were gathered by involving skimming (superficial examination), reading (thorough examination), and interpretation of the information. In addition, unstructured interviews with twelve key informants with expertise, knowledge, and power in policymaking were also done as part of this study. Government officials, academics, and agro-tourism operators, such as lodging, transportation, and agrotourism actors, were among the informants. Indepth interviews with policymakers and users of agro-tourism initiatives were performed to assess the programmes' implementation. The collected data were merged and descriptively analysed, entailing both content and thematic analysis. The former refers to the process of categorising data, whereas the latter is a type of pattern recognition within the data, with emerging themes serving as the categories for analysis [29], [30].

\section{Results and Discussion}

Various parties are involved in the development of tourism, particularly government assistance for policies guiding the growth of agro-tourism. This document analysis, policy analysis in particular, is a type of applied study aimed at better understanding problems and finding better solutions [31], providing information that will aid in the execution of policies. Policy evaluation tries to determine whether policies are being implemented properly and to determine whether policy adjustments are necessary [32]. The purpose of this study's policy analysis was to assess the policies that have been designed and executed to promote agro-tourism. 
The following regulations and policies were examined in this study.

1. Joint Decree of the Minister of Agriculture and the Minister of Tourism, Post and Telecommunications Number: 204/KPTS/HK. 050/4/1989, Number: KM.47/PW.004/MPPT89 concerning the Coordination of AgroTourism Development. This decree regulates cooperation and coordination in agro-tourism development.

2. Decree of the Minister of Agriculture Number 319/Kpts/KP.150/2003 concerning the Agro Tourism Commission. The establishment of an agro commission was specified in this resolution as a means of achieving agrotourism aims. This order establishes the agro commission, which is chaired by the Secretary of the Agricultural Planning Bureau, and the Daily Executive, which is chaired by the Head of the Ministry of Agriculture's Planning and Finance Bureau. The agro-tourism commission's secretariat is based at the Ministry of Agriculture's Bureau of Planning and Finance.

3. Decree of the Minister of Agriculture Number 357/Kpts/HK.350/5/2002 concerning Guidelines for Plantation Business Licensing.

4. Decree of the Minister of Agriculture Number 348/Kpts/TP.240/6/2003 concerning Guidelines for Horticulture Business Licensing. Article 1 paragraph 6 defines agrotourism as an activity that employs horticulture industries as a tourist attraction, as defined in Article 4 paragraph 1 and paragraph 4.

5. Law of the Republic of Indonesia Number 13 of 2010 concerning Horticulture. This Law states about horticulture-based agro-tourism (article 1 paragraph 18), agro-tourism as a horticulture business (article 50), agro-tourism business (article 77 paragraphs 1-6).

6. Government Regulation of the Republic of Indonesia Number 110 of 2015 concerning Agro Horticultural Tourism Business. This government regulation completely regulates horticulture-based agro-tourism businesses, agro-tourism business actors, agro-business units, rights, and obligations, as well as guidance and supervision.

7. Regulation of the President of the Republic of Indonesia Number 64 of 2014 concerning Strategic Coordination of Cross-Sectoral Tourism Implementation. The government coordinates strategic efforts across sectors to ensure that planning, as well as implementation of policies, programmes, and tourism, achieves harmony and integration (article 1 paragraph 3)

8. Decree of the Minister of Manpower and Transmigration of the Republic of Indonesia Number KEP.123/MEN/V/2011 concerning Stipulation of Draft of Indonesian National Work Competency Standards for Tourism Sector in the Field of Agro Tourism Guidance as National Work Competency Standards. This decree serves as a reference for policy formulation and human resource development in the field of agro-tourism scouting.

9. Regulation of the Minister of Tourism of the Republic of Indonesia Number 11 of 2015 concerning the Enforcement of Indonesian National Work Competency Standards in the Tourism Sector (SKKNI). This regulation contains 30 SKKNI standards in the field of tourism. It is stated in article 3 paragraph 12 about the implementation of the SKKNI standards in the field of agro-tourism guidance.

10. Regulation of the Minister of Tourism of the Republic of Indonesia Number 1 of 2018 concerning Amendment to the Ministerial Regulation concerning the Enforcement of Indonesian National Work Competency Standards in the Tourism Sector. There are two additional SKKNI to 32 SKKNI standards in this regulation, where agro-tourism guidance is regulated in article 3 paragraph 10 .

The following are findings from a study of ten policies and interviews with key informants regarding agro-tourism policies. To begin, agrotourism development necessitates collaboration among diverse groups. Agro-tourism is a hybrid tourism idea involving two ministries: the Ministry of Tourism and the the Ministry of Agriculture. The Joint Decree of the Ministers of Agriculture and Tourism, Post, and Telecommunications Number: 204/KPTS/HK. $\quad 050 / 4 / 1989, \quad$ Number: KM.47/PW.004/MPPT-89 concerning Agro Tourism Development with coordination between the two ministries. Planning, utilising, nurturing, and developing agro-tourism activities, as well as financing for cooperation, are all part of the coordination process. Although the development of agro-tourism has been regulated and specified in the cooperation of the two ministries from the beginning, this partnership did not continue in practise due to cabinet changes. The Ministry of Agriculture is still focused on boosting productivity, but other parts of agriculture are less 
important, and cooperation between the two ministries has been lacking.

Furthermore, the Presidential Regulation of the Republic of Indonesia Number 64 of 2014 about Strategic Cooperation of Cross-Sectoral Tourism Implementation regulates cross-sectoral coordination. Despite the fact that cross-sectoral coordination is controlled by a Presidential Regulation, in reality, cross-sectoral coordination is not optimum and tends to demonstrate conspicuous sectoral egos among their respective authority. As a result, tourist implementation programmes must be synchronised, harmonised, and integrated to create synergy. According to the presentation, cooperation is required in the development of agro-tourism, with each ministry minimising its sectoral ego in order for agro-tourism to develop.

Second, in order to enhance agro-tourism, the Minister of Agriculture issued Decree No. 319/Kpts/KP.150/2003, which constituted an agrotourism commission. Its goal is to promote the growth and development of agro-tourism. However, the agro-tourism commission's role and sustainability in the development of agro-tourism are not well defined. The existence of an agrotourism commission is critical in assisting Indonesia's agro-tourism development. It is vital to establish cooperation between the agro-tourism commission and the local government during its implementation in order to identify the issues that have arisen in the development of agro-tourism in the area.

Third, the attractions that exist in agro-tourism of food crops, plantations, horticulture, fisheries, and animal husbandry may have the ability to attract agro-tourism visitors. The Government Regulation of the Republic of Indonesia Number 110 of 2015 concerning Agro Horticultural Tourism Business regulates horticultural agrotourism, which includes fruits, vegetables, medicinal plant ingredients, and floriculture, which includes mushrooms, mosses, and aquatic plants that serve as vegetables, medicinal plant ingredients, and/or aesthetic materials. The Decree of the Minister of Agriculture Number 357/Kpts/HK.350/5/2002 concerning Guidelines for agricultural enterprise licencing regulates plantation agro-tourism. Plantation business, often known as agro-tourism, is an activity that uses plantation business as a tourist attraction to diversify the business, improve job possibilities, and promote plantation business, according to Article 1 paragraph 9.

Fourth, when serving visitors visiting agrotourism, agro-tourism service providers must equip human resources with professional knowledge, skills, and attitudes. As a result, tourists will have an easy time having a memorable and authentic experience. Agro-tourism advisors who can design agro-tourism activities must be knowledgeable about agro-tourism and effective at delivering that information to tourists so that they obtain a thorough understanding of agro-tourism and agriculture. The Indonesian National Work Competency Standard (SKKNI) for agro-tourism guides was established by the government in an effort to promote competent tour guides in the sector of agro-tourism. This is governed by the Minister of Tourism of the Republic of Indonesia's Regulation No. 11 of 2015 on the Enforcement of Indonesian National Work Competency Standards in the Tourism Sector, which has been updated by the Minister of Tourism of the Republic of Indonesia's Regulation No. 1 of 2018 on amendments to Ministerial Regulation No. 11 of 2015.

The Minister of Manpower and Transmigration of the Republic of Indonesia issued Decree Number KEP.123/MEN/V/2011 regulating the determination of the Indonesian National Work Competency Standards for the tourism sector in the field of agro-tourism guidance to become the National Work Competency Standards. It lists several core competencies that agro-tourism guides must possess, including knowledge of agrotourism, skills in planning agro-tourism activities, presenting information on agro-tourism activities, guiding and interpreting agro-tourism activities, as well as minimising tourism activities that endanger visitors and the environment, and evaluating agrotourism activities.

Despite the establishment of the Indonesian National Work Competency Standards for agrotourism, the number of institutions that provide agro-tourism guide certification and implementation locations for agro-tourism competency testing is still quite limited. The majority of tourism certification organisations exclusively certify tour guides and tour leaders, not agro-tourism guides. Because agro-tourism actors in the regions have not certified agro-tourism competencies, limited agro-tourism competencies, attitudes, and knowledge may have an impact on the transfer of knowledge and information provided to tourists, resulting in tourists receiving incomplete information and knowledge about agrotourism. The government has undertaken human resource competency certification in the tourism industry sector, however this is generally the sole certification linked to the hotel industry. As a 
result, in the framework of developing agro-tourism human resources, a finance plan is required, which must be allocated by the government as funding for competency assessments offered to the hotel sector.

Fifth, the Regional Tourism Development Master Plan (RIPPARDA) in Lampung Province does not fully incorporate agro-tourism policies and regulations. This is due to the fact that agro-tourism development in Lampung Province only began in earnest in 2018. The government established an Agro-ecotourism Regional Innovation System (SiDa) at the end of 2018 through the Regional Research and Development Agency, which aims to foster innovation between government institutions, government regions, educational institutions, innovation-supporting institutions, the business world, and local communities for the development of agro-ecotourism. The absence of agro-tourism policies and regulations has a negative impact on the development and sustainability of agro-tourism in Lampung Province, Indonesia.

For the development, promotion, and long-term viability of agro-tourism, government policies are required. This has implications for the central government's function as a tourism facilitator/regulator and a determinant of agrotourism policies. The government has issued several regulations governing policies related to agro-tourism, including those governing crosssectoral cooperation in the development of agrotourism, certification for agro-tourism guides, the formation of agro-tourism commissions, and agrohorticulture business arrangements, according to the findings of this study. However, due to a lack of participation, coordination, and synergy among the parties involved in agro-tourism, regulations and policies are ineffectively implemented. To ensure the success of policies, the central government must plan, coordinate policy execution, and assess policies. The government can work with private sectors to identify problems in the field and expedite efforts to implement current policies. Establishing a local working group comprised of representatives from the public and private sectors as well as the community would be a critical first step [43]-[45].

Local governments, as tourism dynamists, play a critical role in encouraging, planning, overseeing, and evaluating the execution of central government legislation and policies. They also play a part in the development of agro-tourism in the region by providing infrastructure and services. Sectoral egos must be set aside while coordinating and collaborating with agencies. Collaboration can range from activity planning to resource sharing, including finance, information, technology, manpower, and other resources. The provision of infrastructure and services, as well as increased cross-sectoral collaboration for agro-tourism development, are the top priorities for local governments. The absence of agro-tourism from the Master Plan for Regional Tourism Development (RIPPARDA) will have an influence on its development, marketing, and long-term viability in Lampung Province. Local governments must play a part in the planning, development, management, marketing, and sustainability of agro-tourism so that it can flourish and become one of Lampung Province's main tourism potentials.

The findings indicate that government should play a critical role in the development of agrotourism, particularly in terms of policy formulation, marketing and advertisement, financial opportunities, information access, funding, human resources development, and infrastructure [3]-[5], leading to agro-tourism to alleviate rural poverty [46] and diversify economic and social activities [47]. In so doing, government policies can influence tourist destination competitiveness [27], [28].

\section{Conclusion}

Several restrictions regulate the development of agro-tourism, which is governed by government policy. Regrettably, policy implementation still demands further attention and evaluation to guarantee that the policies established are appropriately executed. Because institutional coordination is still lacking, achieving synergies between parties will be difficult. Given the limited number of institutions that conduct competency certification for agro-tourism guides, the competence of agro-tourism guides who follow the Indonesian National Work Competency Standards requires special attention. The government, which includes the Ministry of Agriculture and the Ministry of Tourism and Creative Economy as parties directly involved in agro-tourism development, needs to improve coordination and collaboration, not only in terms of bureaucracy but also in terms of the resources used to develop agrotourism.

The findings of this current study imply that the government increase coordination and collaboration in terms of resources employed to create agro-tourism in general, and specifically in Lampung Province, Indonesia. A policy that governs agro-tourism at the regional level is required, as is the improvement of regional agro- 
tourism guides' competency. Certification of agrotourism guiding competences can improve competency by ensuring that guides have the attitudes, knowledge, and abilities necessary for standardised agro-tourism with government-funded finance schemes. To create greater public-private partnership, the government should take the lead and cultivate an environment conducive to collaboration with the private sector and community, ensuring that tourism develops sustainably and benefits tourists, businesses, and destinations [43]-[45]. The ability of local governments to plan and implement sustainable tourism will benefit local communities, business, tourists, and environment [43].

However, there are several limitations to this research. The findings and consequences of this study may be widened if different methods were employed to analyse the implementation of government agro-tourism legislation and policies targeted at achieving long-term tourism growth in Indonesia. Future studies may use a quantitative way to generalise the current findings. Other developing countries should be studied to see if the findings are comparable and provide more information on the political context of local government.

\section{References:}

[1] M. Kubickova, "The impact of government policies on destination competitiveness in developing economies," Curr. Issues Tour., vol. 22, no. 6, pp. 619-642, 2017, doi: 10.1080/13683500.2017.1296416.

[2] Q. Qin, G. Wall, X. Liu, Q. Qin, G. Wall, and $\mathrm{X}$. Liu, "Government Roles in Stimulating Tourism Development: A Case from Guangxi , China," Asia Pacific J. Tour. Res., vol. 16, no. 5, pp. 471-487, 2011, doi: 10.1080/10941665.2011.597573.

[3] S. N. Zhao and D. J. Timothy, "Governance of red tourism in China: Perspectives on power and guanxi," Tour. Manag., vol. 46, pp. 489-500, 2015, doi: 10.1016/j.tourman.2014.08.011.

[4] M. Kubickova and J. M. Campbell, "The role of government in agro-tourism development: a top-down bottom-up approach bottom-up approach," Curr. Issues Tour., vol. 23, no. 5, pp. 587-604, 2018, doi: 10.1080/13683500.2018.1551338.

[5] L. Ruhanen, "Local government: facilitator or inhibitor of sustainable tourism development?," J. Sustain. Tour., vol. 21, no. 1, pp. 80-98, 2013, doi:
10.1080/09669582.2012.680463.

[6] W. S. Manuela and M. J. De Vera, "The impact of government failure on tourism in the Philippines," Transp. Policy, vol. 43, pp. 11-22, 2015, doi: 10.1016/j.tranpol.2015.05.016.

[7] P. Kemenpar, "Rencana Strategis Kementerian Pariwisata Tahun 2015-2019." Kementerian Pariwisata, Jakarta, p. 142, 2015.

[8] C. Barbieri and P. M. Mshenga, "The Role of the Firm and Owner Characteristics on the Performance of Agritourism Farms," Sociol. Rural., vol. 48, no. 2, pp. 166-183, 2008, $\quad$ doi: $\quad 10.1111 / \mathrm{j} .1467-$ 9523.2008.00450.x.

[9] C. Tew and C. Barbieri, "The perceived bene fi ts of agritourism: The provider' $\mathrm{s}$ perspective," Tour. Manag., vol. 33, pp. 215-224, 2012, doi: 10.1016/j.tourman.2011.02.005.

[10] R. Rambodagedara, D. S. Silva, and S. Perera, "Agro-Tourism Development in Farming Community: Opportunities and Challenges," Sri Lanka, 2015.

[11] S. H. . Malkanthi and J. K. Routry, "Potential For Agritourism Development: Evedance From Sri Lanka," J. Agric. Sci., vol. 6, no. 1, pp. 45-58, 2011, doi: 10.4038/jas.v6i1.3812.

[12] K. Torkington, D. Stanford, and J. Guiver, "Discourse(s) of growth and sustainability in national tourism policy documents," $J$. Sustain. Tour., vol. 28, no. 7, pp. 10411062, 2020, doi: 10.1080/09669582.2020.1720695.

[13] A. Hassan, J. Kennell, and S. Chaperon, "Rhetoric and reality in Bangladesh: elite stakeholder perceptions of the implementation of tourism policy," Tour. Recreat. Res., vol. 0, no. 0, pp. 1-16, 2020, doi: 10.1080/02508281.2019.1703286.

[14] D. L. Edgell, M. D. Allen, G. Smith, and J. R. Swanson, Tourism Policy and Plannning: Yesterday, Today and Tomorrow, vol. 53, no. 9. United Kingdom: Elsevier Inc, 2008.

[15] B. Demirezen, "Agro tourism in Turkey," Int. J. Heal. Manag. Tour., vol. 5, no. 1, pp. 64-75, 2020.

[16] C. T. Putri, B. Wardiyanto, and F. Suaedi, "Policy evaluation of village fund through an agro-tourism village for sustainable local development," Masyarakat, Kebud. dan Polit., vol. 33, no. 2, p. 174, Jun. 2020, doi: 
10.20473/mkp.V33I22020.174-183.

[17] P. Vishwakarma and S. Mukherjee, "Fortythree years journey of Tourism Recreation Research: A bibliometric analysis," Tour. Recreat. Res., vol. 44, no. 4, pp. 403-418, Oct. 2019, doi: 10.1080/02508281.2019.1608066.

[18] M. Spalding and C. L. Parrett, "Global patterns in mangrove recreation and tourism," Mar. Policy, vol. 110, p. 103540, Dec. 2019, doi: 10.1016/j.marpol.2019.103540.

[19] I. Z. Tahir and V. G. Vahid, "Methodological basis of zoning of tourismrecreation reserves and tourism potential of Gusar region of the Republic of Azerbaijan," J. Geol. Geogr. Geoecology, vol. 30, no. 2, pp. 379-388, Jul. 2021, doi: $10.15421 / 112134$.

[20] L. Su, M. K. Hsu, and R. E. Boostrom, "From recreation to responsibility: Increasing environmentally responsible behavior in tourism," J. Bus. Res., vol. 109, pp. 557-573, Mar. 2020, doi: 10.1016/j.jbusres.2018.12.055.

[21] S.-S. Yeh, "Tourism recovery strategy against COVID-19 pandemic," Tour. Recreat. Res., vol. 46, no. 2, pp. 188-194, Apr. 2021, doi: 10.1080/02508281.2020.1805933.

[22] J. Law and V. Singleton, "ANT, multiplicity and policy," Crit. Policy Stud., vol. 8, no. 4, pp. 379-396, 2014, doi: 10.1080/19460171.2014.957056.

[23] C. R. Goeldner and J. R. B. Ritchie, Tourism Principles, Practice, Philosophies, Eleventh E. New Jersey: John Wiley \& Sons, Inc, 2009.

[24] N. A. Morgan, K. A. Whitler, H. Feng, and S. Chari, "Research in marketing strategy," J. Acad. Mark. Sci., vol. 47, no. 1, pp. 4-29, 2019, doi: 10.1007/s11747-018-0598-1.

[25] L. Seong-woo and N. Sou-yeon, "AGROTOURISM AS A RURAL DEVELOPMENT STRATEGY IN KOREA,” J. Rural Dev., vol. 29, no. 6, pp. 67-83, 2006.

[26] E. A. Adu-ampong, "Divided we stand: institutional collaboration in tourism planning and development in the Central Region of Ghana," Curr. Issues Tour., vol. 20, no. 3, pp. 295-314, 2014, doi: 10.1080/13683500.2014.915795.

[27] M. Kubickova, "Tourism Competitiveness , Government and Tourism Area Life Cycle (
TALC ) Model: The Evaluation of Costa Rica , Guatemala and Honduras," Int. J. Tour. Res., vol. 19, no. 2, pp. 223-234, 2017, doi: 10.1002/jtr.2105.

[28] M. Kubickova and D. Martin, "Exploring the relationship between government and destination competitiveness: The TALC model perspective," Tour. Manag., vol. 78, p. 104040, Jun. 2020, doi: 10.1016/j.tourman.2019.104040.

[29] G. A. Bowen, "Document analysis as a qualitative research method," Qual. Res. J., vol. 9, no. 2, pp. 27-40, Aug. 2009, doi: 10.3316/QRJ0902027.

[30] C. Williams, "Research methods," J. Bus. Econ. Res., vol. 5, no. 3, pp. 69-72, Feb. 2011, doi: 10.19030/jber.v5i3.2532.

[31] C. V. Patton, D. S. Sawicki, and J. J. Clark, Basic Methods of Policy, Third. Routedge, 2016.

[32] K. A. Daniell, A. Morton, and D. Ríos Insua, "Policy analysis and policy analytics," Ann. Oper. Res., vol. 236, no. 1, pp. 1-13, 2016, doi: 10.1007/s10479-0151902-9.

[33] M. P. P. dan T. Menparpostel and M. P. Mentan, "Keputusan Bersama Menteri Pertanian dan Menteri Pariwisata, Pos Dan Telekomunikasi Nomor: 204/KPTS/HK. 050/4/1989, Nomor : KM.47/PW.004/MPPT-89 Tentang Koordinasi Pengembangan Wisata Agro.” Kementerian Pariwisata, Pos dan Telekomunikasi dan Departemen Pertanian, Jakarta, pp. 134-140, 1989.

[34] P. Deptan, Keputusan Mentri Pertanian Nomor 319/Kpts/KP.150/2003 Tentang Komisi Wisata Agro. Jakarta: Departemen Pertanian, 2003, pp. 1-4.

[35] M. P. R. I. Mentan, Keputusan Menteri Pertanian nomor 357/Kpts/HK.350/5/2002 Tentang Pedoman Perizinan Usaha Perkebunan. Indonesia, 2002, p. 10.

[36] M. P. R. I. Mentan, Keputusan Menteri Pertanian Nomor 348/Kpts/TP.240/6/2003 Tentang Pedoman Perizinan Usaha Hortikultura. Indonesia, 2003, p. 9.

[37] K. H. dan H. A. M. Kemenkumham, Undang Undang Republik Indonesia Nomor 13 Tahun 2010 Tentang Holtikultura. Jakarta, Indonesia, 2010, pp. 1-84.

[38] K. H. dan H. A. M. Kemenkumham, Peraturan Pemerintah Republik Indonesia Nomor 110 Tahun 2015 Tentang Usaha Wisata Agro Holtikultura. Jakarta, 
Indonesia: Kemenkumham, 2015.

[39] K. H. dan H. A. M. Kemenkumham, Peraturan Presiden Republik Indonesia Nomor 64 Tahun 2014 tentang Koordinasi Strategis Lintas Sektor Penyelenggaraan Kepariwisataan. Indonesia, 2014, pp. 1-20.

[40] M. tenaga K. dan T. R. I. Menakertrans, Keputusan Menteri tenaga Kerja Dan Transmigrasi Republik Indonesia Nomor KEP.123/MEN/V/2011 Tentang Penetapan Rancangan Standar Kompetensi Kerja Nasional Indonesia Sektor Pariwisata Bidang Kepemanduan Wisata Agro Menjadi Standar Kompetensi Kerja Nasional . Indonesia, 2011, pp. 1-70.

[41] Kemenpar, Peraturan Menteri Pariwisata Republik Indonesia Nomor 11 Tahun 2015 Tentang Pemberlakuan Standar Kompetensi Kerja Nasional indonesia Bidang Pariwisata. Indonesia, 2015, pp. 1-7.

[42] K. H. dan H. A. M. Kemenkumham, Peraturan Menteri Pariwisata Republik Indonesia Nomor 1 Tahun 2018 Tentang Perubahan Permen Nomor 11 tahun 2015 Tentang Pemberlakuan Standar Kompetensi Kerja Nasional Indonesia Bidang Pariwisata. Jakarta, Indonesia, 2018, p. 11.

[43] W. Churugsa, A. J. McIntosh, and D. Simmons, "Sustainable tourism planning and development: Understanding the capacity of local government," Leisure/Loisir, vol. 31, no. 2, pp. 453-473, Jan. 2007, doi: 10.1080/14927713.2007.9651391.

[44] Y. G. Worku and G. A. Tessema, "Publicprivate collaboration in the tourism industry in Northwestern Ethiopia," African J. Hosp. Tour. Leis., vol. 7, no. 2, pp. 1-12, 2018.

[45] D. Dredge, "Policy networks and the local organisation of tourism," Tour. Manag., vol. 27, no. 2, pp. 269-280, Apr. 2006, doi: 10.1016/j.tourman.2004.10.003.

[46] K. Allali, "Agricultural landscape externalities, agro-tourism, and rural poverty reduction in Morocco," in Payment for Environmental Services in Agricultural Landscapes, New York, NY: Springer New York, 2009, pp. 189-220.

[47] L. Mura and A. Ključnikov, "Small businesses in rural tourism and agro tourism: Study from Slovakia," Econ. Sociol., vol. 11, no. 3, pp. 286-300, 2018, doi: 10.14254/2071-789X.2018/11-3/17.
Creative Commons Attribution License 4.0 (Attribution 4.0 International, CC BY 4.0) This article is published under the terms of the Creative Commons Attribution License 4.0 https://creativecommons.org/licenses/by/4.0/deed.e n_US 